\title{
PENGARUH KETERAMPILAN, PENGETAHUAN, KONSEP DIRI DAN NILAI-NILAI, DAN KARAKTERISTIK PRIBADI TERHADAP KINERJA PEGAWAI MELALUI KOMITMEN ORGANISASI PADA DISHUBKOMINFO KAB. BANYUMAS
}

\author{
Pipin Widyasari \\ Politeknik Transportasi dan Keselamatan Jalan Tegal \\ pipin_widya@gmail.com
}

\begin{abstract}
To realize vision and mission of Dishubkominfo Banyumas District one of them are to increase public services in traffic and public transportation. So, Dishubkominfo Banyumas District continues to work to improve the quality of to empower all of the employee so that it will have strong performance and can work with optimally, effective, and efficient. The aims of the research are 1) to describe skills, knowledge, concept of self and values, personal characteristic, organization, commitment, and performance; 2) to describe the influence of skill, knowledge, concept of self and values, and personal characteristic to organization commitment; 3) describe the influence of skills, knowledge, concept of self and values, and personal characteristic to performance; 4) describe the influence of organization commitment to employees performance; 5) describe the influence of skill, knowledge, concept of self and values, and personal characteristic to employees performance through organization commitment. Respondent of this research are 100 people. The respondent are the employees of Dishubkominfo Banyumas District. This research using Structural Equation Modeling (SEM) which do by AMOS 4.00 as the instrument of analysis. The result of this research prove that fourth coefficient can be conclude that variable concept of self and values more influence to variable organization commitment, compared with skill variable, knowledge variable, and personal characteristic variable. It can be prove with significantly value of p-value is very small $(0,001)$, so the hypothesis which said there is an influence between variable of skill, knowledge, concept of self and values, personal to variable of organization commitment is attested. From that coefficient it can be conclude that concept of self and values variables is more influence to performance variable compared with the other variable.it can be prove with significantly value of p-value on table column O on output program Amos Ver 19, so the p-values is very small $(0,001)$. Therefore, the hypothesis which said there is an influence between variable of skill, knowledge, concept of self and values, and personal characteristic to performance variable on DishubkominfoBanyumas District is attested. Significantly values of p-value on table column P and the output of Amos Program Ver 19, so the p-value is very small $(<0,001)$, so the hypothesis which said there is an influence between organization commitment to performance of Dishubkominfo Banyumas District is attested. Significantly values of p-value on table column O on output program of Amos Ver 19 which means the value of p-value is very small $(<0,001)$, so the hypothesis which said there is an influence between skill, knowledge, concept of self and values, and personal characteristic to performance through organization commitment on Dishubkominfo Banyumas District is attested.
\end{abstract}

Keywords: skill, knowledge, concept of self and values, personal characteristic, performance, organization commitment. 


\section{PENDAHULUAN}

Undang-Undang Nomor 5 Tahun 2014 tentang Aparatur Sipil Negara tersirat amanat bahwa dalam rangka usaha mencapai tujuan nasional diperlukan pegawai negeri sipil yang berperan sebagai pelayan masyarakat, dengan penuh kesetiaan kepada Pancasila dan Undang-Undang Dasar 1945. Manajemen ASN diselenggarakan berdasarkan Sistem Merit, yang berdasarkan pada kualifkasi, kompetensi, dan kinerja secara adil dan wajar dengan tanpa membedakan latar belakang politik, ras, warna kulit, agama, asal-usul, jenis kelamin, status pernikahan, umum, atau kondisi kecacatan. Manajemen ASN ini meliputi Manajemen Pegawai Negeri Sipil (PNS) dan Manajemen Pegawai Pemerintah dengan Perjanjian Kerja (PPPK) Peranan dan kedudukan Aparatur Sipil Negara (ASN) sangat penting dan menentukan karena pegawai negeri merupakan unsur aparatur negara dalam menyelenggarakan tugas-tugas pemerintahan dan pembangunan dalam rangka mencapai tujuan nasional.

Anggaran Negara yang dibelanjakan untuk kepentingan pegawai negeri dari tahun ke tahun mengalami kenaikan, namun hal tersebut belum diimbangi dengan peningkatan profesionalisme dan integritas yang tinggi bagi komunitas Aparatur Sipil Negara. Belanja pegawai adalah semua pengeluaran negara yang digunakan untuk membiayai kompensasi dalam bentuk uang atau barang yang diberikan kepada pegawai pemerintah pusat, pensiunan, anggota Tentara Nasional Indonesia/Kepolisian Negara Republik Indonesia, dan pejabat negara, baik yang bertugas di dalam negeri maupun di luar negeri, sebagai imbalan atas pekerjaan yang telah dilaksanakan, kecuali pekerjaan yang berkaitan dengan pembentukan modal.

Dalam upaya mengatasi permasalahan ini, para pengambil kebijakan dapat melakukan perbaikan kedalam, yang salah satunya melalui pengembangan sumber daya manusia. Perbaikan kondisi internal ini sekaligus bertujuan untuk memperkuat diri dan meningkatkan daya tahan dalam menghadapi persaingan lokal dan global yang pasti akan semakin ketat. Ini artinya instansi harus memperbaiki sistem manajemen kinerja instansinya melalui perbaikan kinerja pegawainya, karena keberhasilan instansi dalam memperbaiki kinerja instansinya sangat tergantung pada kualitas sumber daya manusia yang bersangkutan dalam berkarya atau bekerja.

Bekerja merupakan kegiatan manusia untuk mengubah keadaan tertentu dari suatu alam lingkungan. Perubahan ini ditujukan untuk memenuhi kebutuhan hidup dan memelihara hidup yang pada dasarnya untuk memenuhi tujuan hidup. Pada dasarnya kebutuhan hidup manusia tersebut tidak hanya berupa material, tetapi juga bersifat non-material seperti kebanggaan dan kepuasan kerja. Di dalam proses mencapai kebutuhan yang diinginkan, tiap individu cenderung akan dihadapkan pada hal-hal baru yang mungkin tidak diduga sebelumnya, sehingga melalui bekerja dan pertumbuhan pengalaman, seseorang akan memperoleh kemajuan dalam hidupnya. Dalam proses bekerja itulah seseorang dapat dilihat bagaimana kinerjanya.

Kinerja adalah hasil atau tingkat keberhasilan seseorang secara keseluruhan selama periode tertentu dalam melaksanakan tugas dibandingkan dengan berbagai kemungkinan, seperti standar hasil kerja, target atau sasaran maupun kriteria yang ditentukan terlebih dahulu dan telah disepakati bersama. Jika dilihat dari asal katanya, kata kinerja berasal dari kata performance, yang menurut The Scribner-Bantam English Dictionary (dalam Rivai dan Basri, 2005:14) berasal 
dari akar kata to perform yang mempunyai beberapa masukan (entries), yakni (1) melakukan, menjalankan, melaksanakan (to do or carry out execute); (2) memenuhi atau melaksanakan kewajiban suatu niat atau nazar (to dischange of fulfill; as vow); (3) melaksanakan atau menyempurnakan tanggung jawab (to execute or complete an understanding); (4) melakukan sesuatu yang diharapkan oleh seseorang atau mesin (to do what is expected of a person machine). Dari masukan tersebut dapat diartikan, kinerja adalah melakukan suatu kegiatan dan menyempurnakan pekerjaan tersebut sesuai dengan tanggung jawabnya sehingga dapat mencapai hasil sesuai dengan yang diharapkan.

Kinerja dalam menjalankan fungsinya tidak berdiri sendiri, tetapi berhubungan dengan kemampuan dan motivasi kerja. Oleh karena itu menurut Keith Davis (dalam Mangkunegara, 2005:13), ada dua faktor utama yang mempengaruhi kinerja individu yakni kemampuan (ability), dan motivasi kerja (motivation) individu tersebut. Kemampuan individual tergantung dari tingkat pengetahuan (knowledge) yang dimiliki, latar belakang pendidikan, dan keterampilan (skill) yang dikuasai. Sedangkan motivasi kerja individual tergantung sikap (attitude) sebagai motivasi dasar dan lingkungan yang mempengaruhi motivasi tersebut.

Oleh karena itu, pembinaan dan peningkatan kinerja individu dapat dilakukan dengan pembinaan dan peningkatan kemampuan dan motivasi kerja yang dimiliki. Peningkatan kemampuan kerja dilakukan dengan upaya peningkatan aspek-aspek yang mendasari unsur tersebut yakni pengetahuan dan keterampilan kerja individu serta peningkatan motivasi kerja dilakukan dengan cara membina sikap mental individu serta situasi/lingkungan yang mendorong timbulnya kepuasan dan kemauan kerja individu.

Untuk mewujudkan visi dan misi Dishubkominfo Kab. Banyumas diantaranya adalah untuk meningkatkan pelayanan umum dibidang lalu lintas dan angkutan jalan, meningkatkan kualitas dan kuantitas perlengkapan jalan, meningkatkan kualitas kelaikan jalan, meningkatkan pelayanan desiminasi, informasi serta pengaturan, pengawasan sarana komunikasi pos dan telekomunikasi, meningkatkan kualitas sumber daya aparatur perhubungan, komunikasi dan informatika. Maka Dishubkominfo $\mathrm{Kab}$. Banyumas terus berupaya meningkatkan kualitas dengan memberdayakan seluruh pegawai agar dapat bekerja secara optimal, efektif dan efisien.

Kinerja Individu adalah hasil kerja pegawai baik dari segi kualitas maupun kuantitas berdasarkan standar kerja yang telah ditentukan. Pegawai yang produktif menggambarkan potensi, persepsi, dan kreativitas seseorang yang senantiasa ingin menyumbangkan kemampuan agar bermanfaat bagi diri dan lingkungannya. Jadi, pegawai yang produktif adalah orang yang dapat memberi sumbangan yang nyata, imaginatif dan inovatif dalam mendekati persoalan hidupnya serta mempunyai kepandaian (kreatif) dalam mencapai tujuan hidupnya, bertanggung jawab dan responsif dalam hubungannya dengan orang lain (kepemimpinan). Pegawai seperti ini merupakan aset organisasi yang selalu berusaha meningkatkan diri dalam organisasinya, dan akan menunjang pencapaian produktivitas organisasi.

Oleh karena itu, organisasi perlu melakukan upaya akuisisi atau pengembangan kompetensi secara sistematis. Pengembangan kompetensi dapat dilakukan dengan pembinaan dan peningkatan kemampuan dan motivasi kerja yang dimiliki. Peningkatan kemampuan kerja 
dilakukan dengan upaya peningkatan aspek-aspek yang mendasari unsur tersebut yakni pengetahuan dan keterampilan kerja individu serta peningkatan motivasi kerja dilakukan dengan cara membina sikap mental individu serta situasi/lingkungan yang mendorong timbulnya kepuasan dan kemauan kerja individu.

Seirama dengan perkembangan ilmu pengetahuan dan teknologi yang cepat serta persaingan yang begitu ketat dan tuntutan reformasi maka seluruh komponen Dinas Perhubungan dan komunikasi Kab. Banyumas termasuk seluruh pegawai, turut serta mendukung dalam meningkatkan kualitas pendidikan secara berkesinambungan. Kebutuhan tenaga-tenaga terampil didalam berbagai bidang sudah merupakan tuntutan dunia global yang tidak dapat ditunda dan dituntut untuk memiliki kemampuan dalam membuat rencana pengembangan SDM yang berkualitas, dengan melakukan perbaikan kedalam, yang salah satunya melalui pengembangan SDM. Dengan perbaikan kondisi internal ini sekaligus bertujuan untuk memperkuat diri dan meningkatkan daya tahan dalam menghadapi persaingan lokal dan global yang akan semakin ketat.

Dalam pelaksanaan tugas dan fungsi Dinas Perhubungan dan Komunikasi Kab. Banyumas, maka dukungan kualitas sumber daya aparatur menjadi sebuah keharusan. Kualitas sumber daya manusia (SDM) merupakan salah satu faktor untuk meningkatkan produktivitas kinerja suatu organisasi atau instansi. Oleh karena itu, diperlukan sumber daya manusia yang mempunyai kompetensi tinggi karena kompetensi akan dapat mendukung peningkatan prestasi kinerja pegawai. Selama ini banyak instansi pemerintah yang belum mempunyai pegawai dengan kompetensi yang memadai, ini dibuktikan dengan rendahnya produktivitas pegawai dan sulitnya mengukur kinerja pegawai di lingkup instansi pemerintah. Selama ini penilaian prestasi kinerja pegawai menggunakan DP 3 yang didalam terdapat 8 (delapan) unsur, yaitu kejujuran, kesetiaan, ketaatan, prestasi kerja, tanggung jawab, kerjasama, kepemimpinan dan prakarsa atau sekarang disebut dengan Sasaran Kerja Pegawai (SKP).

Harapan terhadap professionalisme ASN ini dilatarbelakangi oleh adanya kesenjangan antara kinerja yang diharapkan (intended performance) dengan kinerja nyata yang dihasilkan (actual performance) oleh ASN. Masih banyaknya tingkat inefisiensi dalam pelaksanaan tugas merupakan bukti nyata kompetensi yang masih rendah. ASN yang kurang professional dan kurang memiliki kesadaran moral cenderung melakukan penyalahgunaan wewenang atau penyalahgunaan keuangan negara. Perilaku ASN yang menyimpang tersebut akan menjadi permasalahan yang rumit, manakala ASN belum mampu beradaptasi dengan dinamika perubahan lingkungan termasuk kurang peka menghadapi perkembangan ilmu pengetahuan dan teknologi serta sulit untuk memperbaiki kinerjanya (http://www.bkn.go.id. 2004).

Dalam pengamatan penulis pada Instansi di Dishubkominfo Kab. Banyumas seharusnya bisa menjadi barometer dalam pencapaian kinerja yang tinggi. Namun, kenyataan empirik menunjukkan bahwa kinerja pegawai tidak maksimal. Hal ini tampak adanya aktivitas yang dilakukan sebagian Pegawai Negeri yang tidak produktif, ada sekitar 33 orang dari 130 orang atau $25 \%$ pegawai terlambat masuk kantor dan pulang tidak tepat waktu (sumber: Laporan rekapitulasi kehadiran staf administrasi), tidak adanya pelatihan untuk staf 2 tahun terakhir, tidak profesionalnya dalam pelayanan, Ada kecenderungan pegawai 
menunda pekerjaan, menunggu perintah atasan.

Berdasarkan uraian tersebut, penulis merasa tertarik untuk melakukan penelitian dengan melanjutkan penelitian terdahulu juga oleh penulis mengenai faktor-faktor yang mempengaruhi kinerja pegawai pada Dishubkominfo Kab. Banyumas dan pada penelitian ini, penulis mengangkat judul "Pengaruh Keterampilan, Pengetahuan, Konsep Diri Dan Nilai-Nilai, Dan Karakteristik Pribadi Terhadap Kinerja Pegawai Melalui Komitmen Organisasi Pada Dishubkominfo Kab.Banyumas". Pegawai dalam penelitian ini adalah Kepala Dinas, Sekretariat, Kasubbag, Subbag, Kabid dan semua pegawai yang ada di Lingkungan Dishubkominfo Kab. Banyumas.

\section{METODE PENELITIAN}

Metode Penelitin dan Analisis data serta interpretasi untuk penelitian yang ditujukan untuk menjawab pertanyaan-pertanyaan penelitian dalam rangka mengungkap fenomena social tertentu. Analisis data adalah proses penyederhanaan data ke dalam bentuk yang lebih mudah dibaca diimplementasikan. Metode yang dipilih untuk menganalisis data harus sesuai dengan pola penelitian dan variable yang akan diteliti. Untuk menganalisis data digunakan The Structural Equation Modeling (SEM) dari paket software statistik AMOS 19 dalam model dan pengkajian hipotesis. Model persamaan struktural, Structural Equation Model (SEM) adalah sekumpulan teknik-teknik statistical yang memungkinkan pengujian sebuah rangkaian hubungan relatif "rumit" secara simultan (Ferdinand, 2011).

Alasan penelitian ini dilakukan dengan SEM dikarenakan dalam model penelitian ini digunakan variable intervening disamping itu masing-masing variable diukur melalui indikatorindikator sehingga perlu dilakukan uji kelayakan model apakah model yang dianalisis dalam penelitian ini sesuai dengan keadaan yang sebenarnya. Tampilnya model yang rumit membawa dampak bahwa dalam kenyataannya proses pengambilan keputusan manajemen adalah sebuah proses yang yang rumit atau merupakan sebuah proses yang multidimensional dengan berbagai pola hubungan kausalitas yang berjenjang. Oleh karenanya dibutuhkan sebuah model sekaligus alat analisis yang mampu mengakomodasi penelitian multidimensional itu.

Keunggulan aplikasi SEM dalam penelitian manajemen adalah karena kemampuannya untuk mengkonfirmasi dimensi-dimensi dari sebuah konsep atau faktor yang sangat lazim digunakan dalam manajemen serta kemempuannya untuk mengukur pengaruh hubunganhubungan yang secara teoritis ada (Ferdinand, 2011). 


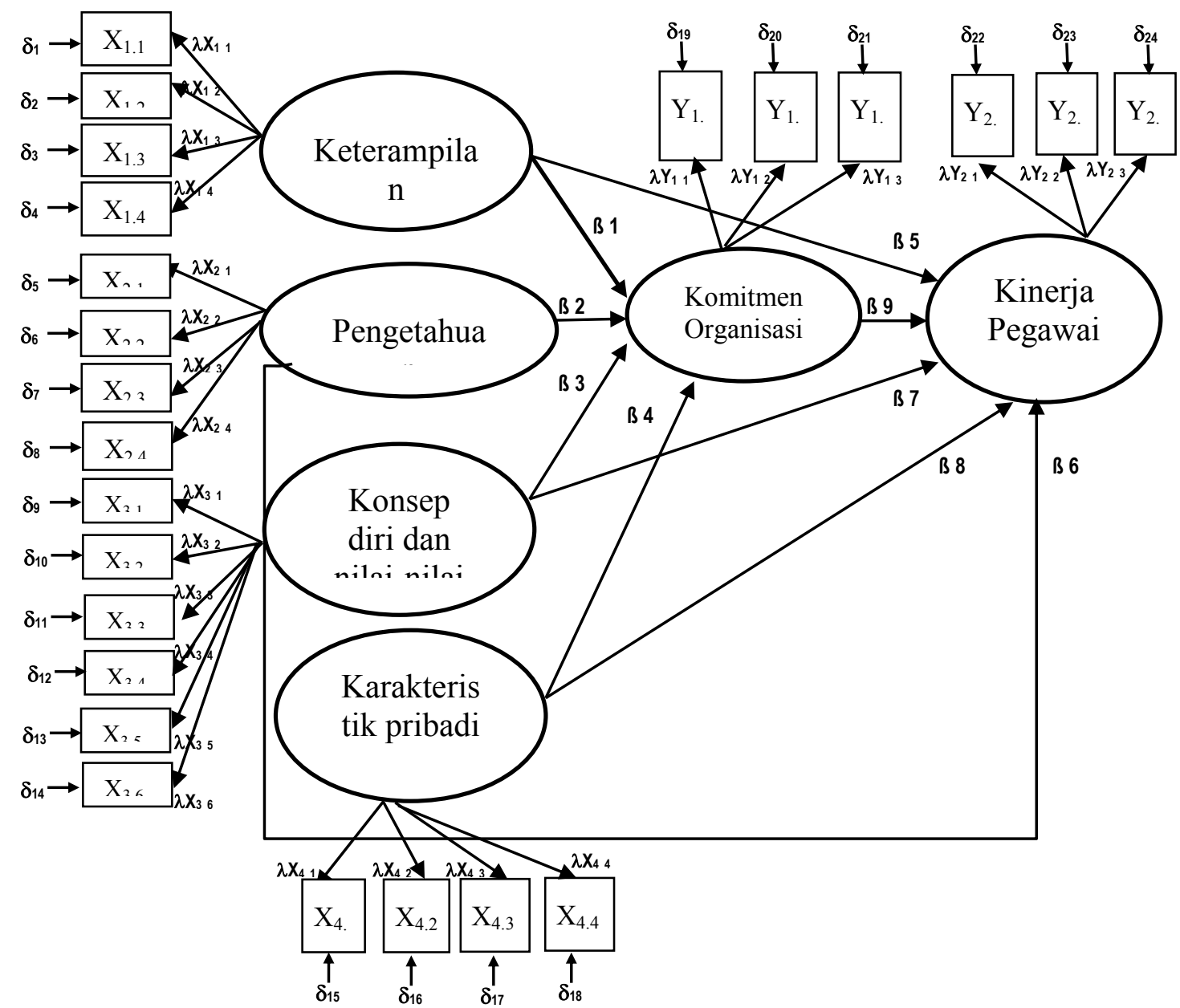

Gambar 1

Model Persamaan Struktural

\section{HASIL DAN PEMBAHASAN}

\section{Karakteristik Pesepsi Responden}

Analisis ini dilakukan untuk mendapatkan gambaran deskriftif mengenai responden penelitian ini, khususnya mengenai variabel-variabel penelitian yang digunakan. Analisis ini dilakukan dengan menggunakan teknik analisis statistik deskriptif dan indeks, untuk menggambarkan persepsi responden atas item-item pertanyaan yang diajukan. Dengan dasar ini, peneliti menentukan indeks persepsi responden terhadap variabel-variabel yang digunakan dalam penelitian ini. (Ferdinand, 2011).
Tabel 1

Indeks Variabel Keterampilan

\begin{tabular}{|c|c|c|c|c|c|c|}
\hline \multirow{2}{*}{$\begin{array}{c}\text { Dimensi } \\
\text { Keteram- } \\
\text { pilan }\end{array}$} & \multicolumn{5}{|c|}{ Frekuensi Jawaban Responden } & \multirow{2}{*}{$\begin{array}{c}\text { Indeks } \\
(\%)\end{array}$} \\
\hline & 1 & 2 & 3 & 4 & 5 & \\
\hline $\begin{array}{l}\text { Concern } \\
\text { for order }\end{array}$ & 0 & 0,13 & 1,40 & 43,73 & 42,67 & 87,9 \\
\hline Initiative & 0 & 0 & 5,10 & 50,00 & 29,00 & 84,1 \\
\hline $\begin{array}{l}\text { Impact and } \\
\text { influence }\end{array}$ & 0 & 0 & 0 & 38,13 & 52,33 & 90,5 \\
\hline $\begin{array}{c}\text { Information } \\
\text { seeking }\end{array}$ & 0 & 0 & 11,10 & 48,00 & 21,50 & 80,6 \\
\hline \multicolumn{6}{|c|}{ Total Indeks } & 85,78 \\
\hline
\end{tabular}

Sumber: Data Primer Diolah, 2016

Tabel di atas menunjukkan bahwa dari rentang nilai indeks sebesar 10-100, rata-rata indeks Variabel Keterampilan adalah tinggi yakni 
sebesar $85,78 \%$. Hal ini menunjukkan bahwa responden berpendapat bahwa Persepsi keterampilan pegawai pada Dishubkominfo Kab. Banyumas tinggi. Dalam tabel tersebut diketahui bahwa Information seeking menempati posisi terendah dalam variabel keterampilan, yakni $80,6 \%$. Sedangkan posisi tertinggi persepsi keterampilan pada dimensi Impact and influence yakni sebesar 90,5\%, dimensi Concern for order memperoleh indek sebesar $87,9 \%$ dan dimensi Initiative memperoleh indek sebesar 84,1\%. Hal ini menunjukkan bahwa keempat dimensi tersebut dapat dijadikan tolok ukur dari variabel keterampilan.

Tabel 2

Indeks Variabel Pengetahuan

\begin{tabular}{|c|c|c|c|c|c|c|}
\hline \multirow{2}{*}{ Dimensi } & \multicolumn{5}{|c|}{ Frekuensi Jawaban Responden } & \multirow{2}{*}{$\begin{array}{c}\text { Indeks } \\
\text { (\%) }\end{array}$} \\
\cline { 2 - 6 } & $\mathbf{1}$ & $\mathbf{2}$ & $\mathbf{3}$ & $\mathbf{4}$ & $\mathbf{5}$ & \\
\hline Pendidikan & 0,20 & 1,73 & 7,60 & 34,67 & 38,67 & 82,9 \\
\hline Pengalaman & 0,10 & 2,80 & 8,70 & 36,00 & 3,00 & 80,6 \\
\hline Usia & 0 & 1,20 & 8,40 & 37,60 & 36,00 & 83,2 \\
\hline Informasi & 0 & 0,10 & 5,70 & 40,60 & 39,50 & 85,9 \\
\hline \multicolumn{7}{|c|}{ Total Indeks } \\
\hline Sumber: Data Primer Diolah, 2016
\end{tabular}

Tabel di atas menunjukkan bahwa dari rentang nilai indeks sebesar 10-100, rata-rata indeks variabel pengetahuan adalah tinggi yakni sebesar $83,10 \%$. Hal ini menunjukkan bahwa responden sudah sangat mengerti bahwa pengetahuan pegawai sangat dipengaruhi oleh keempat demensi tersebut. Dalam tabel tersebut diketahui bahwa dimensi informasi merupakan dimensi tertinggi dengan memperoleh nilai indeks sebesar $85,9 \%$, kemudian diikuti dengan dimensi Usia dengan memperoleh nilai indeks sebesar 83,2\%, kemudian dimensi pendidikan dengan memperoleh nilai indeks sebesar $82,9 \%$, dan yang terakhir adalah dimensi pengalaman diposisi terendah dalam variabel pengetahuan, yakni $80,6 \%$. Hal ini menunjukkan bahwa keempat dimensi tersebut menjadi tolok ukur dari variabel pengetahuan.

Tabel 3

Indeks Variabel Konsep Diri dan Nilai-Nilai

\begin{tabular}{|c|c|c|c|c|c|c|}
\hline \multirow{2}{*}{ Dimensi } & \multicolumn{5}{|c|}{ Frekuensi Jawaban Responden } & \multirow{2}{*}{$\begin{array}{c}\text { Indeks } \\
(\%)\end{array}$} \\
\hline & 1 & 2 & 3 & 4 & 5 & \\
\hline $\begin{array}{c}\text { Developing } \\
\text { others }\end{array}$ & 0 & 0,80 & 8,40 & 41,60 & 32,00 & 82,8 \\
\hline $\begin{array}{c}\text { Directiveness } \\
\text { assertiveness } \\
\text { and use of } \\
\text { positional } \\
\text { power }\end{array}$ & 0 & 1,00 & 14,10 & 38,40 & 26,00 & 79,5 \\
\hline $\begin{array}{l}\text { Teamwork } \\
\text { and } \\
\text { cooperation }\end{array}$ & 0,10 & 2,00 & 9,90 & 40,40 & 27,50 & 79,9 \\
\hline $\begin{array}{c}\text { Team } \\
\text { leadership }\end{array}$ & 0 & 1,80 & 13,80 & 35,60 & 28,00 & 79,2 \\
\hline $\begin{array}{l}\text { Interpersonal } \\
\text { understanding }\end{array}$ & 0 & 1,40 & 14,70 & 39,20 & 23,00 & 78,3 \\
\hline $\begin{array}{l}\text { Customer } \\
\text { service } \\
\text { orientation }\end{array}$ & 0 & 1,20 & 13,20 & 37,60 & 28,00 & 80,0 \\
\hline \multicolumn{6}{|c|}{ Total Indeks } & 80,0 \\
\hline
\end{tabular}

Sumber: Data Primer Diolah, 2016

Tabel di atas menunjukkan bahwa dari rentang nilai indeks sebesar 10-100, rata-rata indeks variabel konsep diri dan nilai-nilai adalah tinggi yakni sebesar $80 \%$. Hal ini menunjukkan bahwa responden berpendapat bahwa persepsi konsep diri dan nilai-nilai pegawai pada Dishubkominfo Kab. Banyumas sudah sangat baik dalam menjalankan tata kerja dan tata pamong dalam instansi. Dimensi dalam variabel konsep diri dan nilai-nilai terdapat Developing others tergolong baik dengan memperoleh indeks sebesar $82,8 \%$, dan diikuti dengan Customer service orientation yang memperoleh indek sebesar $80 \%$, dan Teamwork and cooperation memperoleh indek 79,9\% sedangkan Directiveness assertiveness and use of positional power tergolong baik dengan memperoleh indeks sebesar 79,5\%, Team leadership memeperoleh indeks sebesar 79,2\% dan Interpersonal understanding memperoleh indeks sebesar 78,3\%. 
Tabel 4

Indeks Variabel Karakteristik Pribadi

\begin{tabular}{|c|c|c|c|c|c|c|}
\hline \multirow{2}{*}{ Dimensi } & \multicolumn{5}{|c|}{ Frekuensi Jawaban Responden } & \multirow{2}{*}{$\begin{array}{c}\text { Indeks } \\
\text { (\%) }\end{array}$} \\
\cline { 2 - 6 } & $\mathbf{1}$ & $\mathbf{2}$ & $\mathbf{3}$ & $\mathbf{4}$ & $\mathbf{5}$ & \\
\hline Self Control & 0 & 0,13 & 4,60 & 43,73 & 37,33 & 85,8 \\
\hline Self Confidence & 0 & 0 & 5,10 & 41,60 & 39,50 & 86,2 \\
\hline Flexibility & 0 & 0 & 0,30 & 28,80 & 63,50 & 92,6 \\
\hline $\begin{array}{c}\text { Organizational } \\
\text { Commitment }\end{array}$ & 0 & 0 & 0 & 38,13 & 52,33 & 90,4 \\
\hline \multicolumn{7}{|c|}{ Total Indeks } \\
\hline
\end{tabular}

Sumber: Data Primer Diolah, 2016

Tabel di atas menunjukkan bahwa dari rentang nilai indeks sebesar 10-100, rata-rata indeks Variabel Karakteristik Pribadi adalah tinggi yakni sebesar 88,8\%. Hal ini menunjukkan bahwa responden merasa pecaya diri dalam melaksanakan tugas terhadap pekerjaan yang dilakukannya. Dalam tabel tersebut diketahui bahwa besarnya percaya diri pegawai dapat digambarkan dalam dimensi variabel karakteristik pribadi yang tertinggi adalah dalam Flexibility dengan memperoleh nilai 92,6\%. Kemudian diikuti oleh Organizational Commitment sebesar 90,4\%, kemudian Self Confidence memperoleh imbalan sebesar $86,2 \%$, dan Self Control sebesar 85,8\%. Hal ini menunjukkan bahwa keempat dimensi tersebut dapat dijadikan tolok ukur dari variabel Karakteristik Pribadi.

Tabel 5

Indeks Variabel Komitmen Organisasi

\begin{tabular}{|c|c|c|c|c|c|c|}
\hline \multirow{2}{*}{ Dimensi } & \multicolumn{7}{|c|}{ Frekuensi Jawaban Responden } & \multirow{2}{*}{\begin{tabular}{c} 
Indeks \\
\cline { 2 - 6 }
\end{tabular}} & $\mathbf{1}$ & $\mathbf{2}$ & $\mathbf{3}$ & $\mathbf{4}$ & $\mathbf{5}$ & \\
\hline Afektif & 0 & 0,10 & 1,05 & 45,40 & 41,25 & 87,8 \\
\hline Berkelanjutan & 0 & 0 & 0 & 50,40 & 37 & 87,4 \\
\hline Normatif & 0 & 0 & 3 & 49,33 & 33,33 & 85,7 \\
\hline \multicolumn{7}{|c|}{ Total Indeks } \\
\hline Sumber: Data Primer Diolah, 2016
\end{tabular}

Tabel di atas menunjukkan bahwa dari rentang nilai indeks sebesar 10-100, rata-rata indeks Variabel Komitmen Organisasi adalah tinggi yakni sebesar $87 \%$. Hal ini menunjukkan bahwa responden berpendapat bahwa komitmen organisasi pegawai sangat komit terhadap tugas dan beban yang menjadi tanggungjawabnya. Dalam tabel tersebut diketahui bahwa afektif dimensi yang memperoleh nilai tertinggi dalam variabel komitmen organisasi, yakni sebesar 87,8\%. Kemudian diikuti oleh berkelanjutan sebesar $87,4 \%$, dan yang terendah adalah normative sebesar $85,7 \%$, Hal ini menunjukkan bahwa ketiga dimensi tersebut dapat dijadikan tolok ukur dari variabel Komitmen Organisasi.

Tabel 6

Indeks Variabel Kinerja

\begin{tabular}{|c|c|c|c|c|c|c|}
\hline \multirow{2}{*}{ Dimensi } & \multicolumn{5}{|c|}{ Frekuensi Jawaban Responden } & \multirow{2}{*}{$\begin{array}{c}\text { Indeks } \\
(\%)\end{array}$} \\
\hline & 1 & 2 & 3 & 4 & 5 & \\
\hline $\begin{array}{c}\text { Prestasi } \\
\text { Kerja }\end{array}$ & 0 & 0 & 0,80 & 42,13 & 46 & 88,9 \\
\hline Kepribadian & 0 & 0,67 & 5,8 & 47,2 & 29,67 & 83,3 \\
\hline $\begin{array}{c}\text { Kemampuan } \\
\text { Kerja }\end{array}$ & 0 & 2,1 & 7,5 & 39,6 & 32,75 & 82 \\
\hline \multicolumn{6}{|c|}{ Total Indeks } & 84,7 \\
\hline
\end{tabular}

Tabel di atas menunjukkan bahwa dari rentang nilai indeks sebesar 10-100, rata-rata indeks Variabel Kinerja Pegawai adalah tinggi yakni sebesar $84,7 \%$. Hal ini menunjukkan bahwa responden berpendapat bahwa kinerja pegawai tinggi. Dalam tabel tersebut diketahui bahwa dimensi prestasi kerja posisi tertinggi dalam variabel kinerja pegawai, yakni sebesar $88,9 \%$. Kemudian diikuti oleh kepribadian sebesar $83,3 \%$, dan yang terendah kemampuan kerja sebesar 82\%, Hal ini menunjukkan bahwa ketiga dimensi tersebut dapat dijadikan tolok ukur dari variabel Kinerja Pegawai.

\section{Analisis Asumsi Structural Equating Modeling (SEM)}

Untuk melakukan analisis inferensial dalam penelitian ini digunakan teknik Structural Equation Modeling (SEM). Dalam melakukan analisis 
dengan teknik Structural Equation Modeling (SEM), estimasi dilakukan secara bertahap, yaitu pertama, dengan melakukan teknik Confirmatory Factor Analysis. Analisis Faktor Konfirmatori (Confirmatory Factor Analysis) disebut sebagai teknik analisis faktor konfirmatori sebab pada tahap ini model akan mengkonfirmasi apakah variabel yang diamati dapat mencerminkan faktor yang dianalisis. Unidimensionalitas dari dimensi-dimensi itu diuji melalui confirmatory factor analysis yang hasilnya seperti yang disajikan berikut ini.

\section{a. Analisis Konfirmatori Variabel Keterampilan $\left(\mathbf{X}_{1}\right)$}

Analisis konfirmatori variabel keterampilan dilakukan untuk mengkonfirmasi apakah indikator yang diamati dapat mencerminkan faktor yang Dianalisis yaitu variabel keterampilan. Adapun hasil analisis konfirmatori yang dilakukan terhadap variabel keterampilan diuraikan di bawah ini :
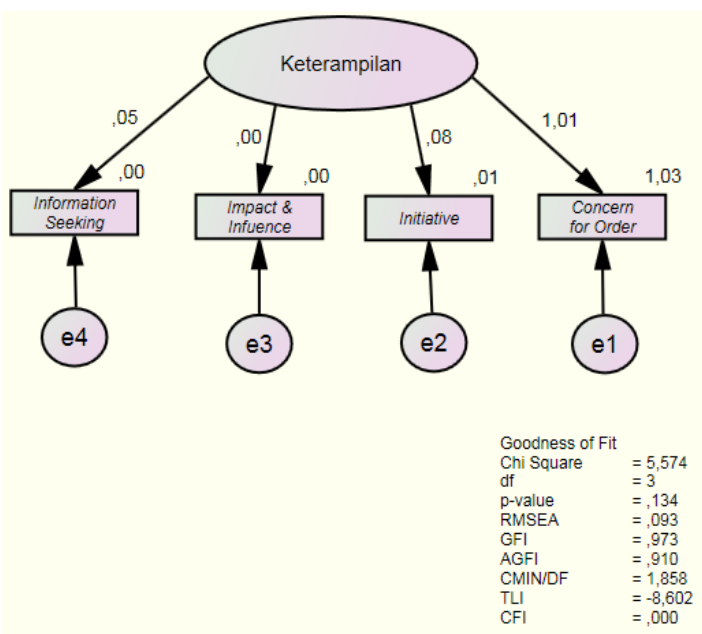

Gambar 2

Hasil Analisis Konfirmatori Variabel Keterampilan

Untuk melakukan analisis konfirmatori variabel keterampilan, uji dasar yang harus dilakukan yaitu dengan menguji kesesuaian model-Goodness of Fit Test, hasil pengujian kesesuaian model pada konfirmatori factor analisis disajikan dalam Tabel di bawah ini :

Tabel. 7

Hasil Pengujian Kelayakan Variabel Keterampilan

\begin{tabular}{|l|c|c|c|}
\hline $\begin{array}{c}\text { Goodness of } \\
\text { Fit Indeks }\end{array}$ & $\begin{array}{c}\text { Cut off } \\
\text { Value }\end{array}$ & Hasil & Evaluasi Model \\
\hline Chi-Square & $\leq 7,81$ & 5,574 & Memenuhi \\
\hline DF & $\geq 0,05$ & 0,134 & Memenuhi \\
\hline P-Value & $\leq 0,08$ & 0,093 & Tidak Memenuhi \\
\hline RMSEA & $\geq 0,90$ & 0,973 & Memenuhi \\
\hline GFI & $\geq 0,90$ & 0,910 & Memenuhi \\
\hline AGFI & $\leq 2,00$ & 1,858 & Memenuhi \\
\hline CMIN/DF & $\geq 0,95$ & $-8,602$ & Memenuhi \\
\hline TLI & $\geq 0,95$ & 0,000 & Marginal \\
\hline CFI & Sumber: Data Primer Diolah, 2016
\end{tabular}

Dari Tabel di atas menunjukkan bahwa nilai Chi Square $=5,574$ dengan tingkat signifikansi sebesar 7,81 demikian pula dengan nilai kelayakan yang lain yang memenuhi kriteria fit sehingga dapat disimpulkan bahwa tidak terdapat perbedaan antara matriks kovarians sample dengan matriks kovarians populasi yang diestimasi diterima yang berarti model adalah fit. Sehingga secara keseluruhan model dapat diterima untuk memberikan konfirmasi yang cukup sehingga keempat indicator yang digunakan dapat mencerminkan variabel laten yang dianalisis yaitu variable keterampilan.

\section{b. Analisis Konfirmatori Variabel Pengetahuan $\left(\mathrm{X}_{2}\right)$}

Analisis konfirmatori variabel pengetahuan dilakukan untuk mengkonfirmasi apakah indikator yang diamati dapat mencerminkan faktor yang Dianalisis yaitu variabel pengetahuan. Adapun hasil analisis konfirmatori yang dilakukan terhadap variabel pengetahuan diuraikan di bawah ini : 


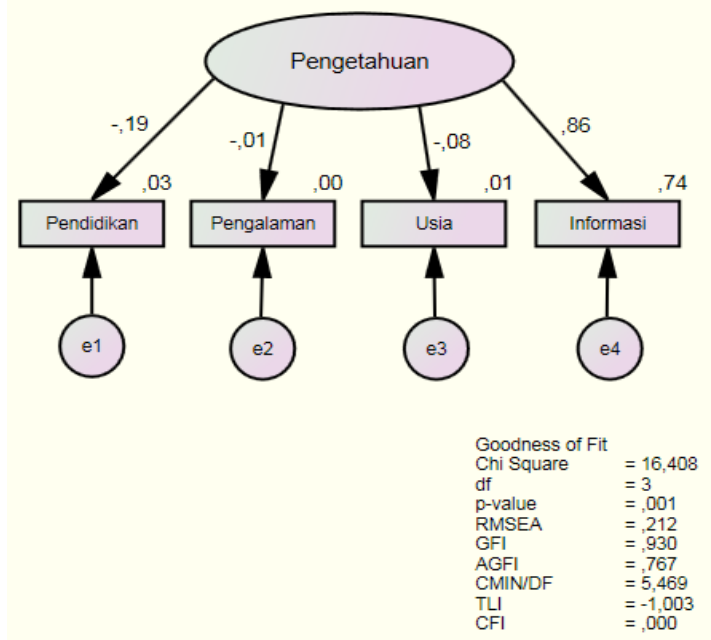

Gambar 3

Hasil Analisis Konfirmatori Variabel Pengetahuan

Untuk melakukan analisis konfirmatori variabel pengetahuan, harus dilakukan penguji kesesuaian modelGoodness of Fit Test, hasil pengujian kesesuaian model pada konfirmatori factor analisis disajikan dalam Tabel di bawah ini :

Tabel 8

Hasil Pengujian Kelayakan Variabel Pengetahuan

\begin{tabular}{|l|c|c|c|}
\hline $\begin{array}{c}\text { Goodness of } \\
\text { Fit Indeks }\end{array}$ & $\begin{array}{c}\text { Cut off } \\
\text { Value }\end{array}$ & Hasil & Evaluasi Model \\
\hline Chi-Square & $\leq 7,81$ & 16,408 & $\begin{array}{c}\text { Tidak } \\
\text { Memenuhi }\end{array}$ \\
\hline DF & $\geq 0,05$ & 0,001 & $\begin{array}{c}\text { Tidak } \\
\text { Memenuhi }\end{array}$ \\
\hline P-Value & $\leq 0,08$ & 0,212 & $\begin{array}{c}\text { Tidak } \\
\text { Memenuhi }\end{array}$ \\
\hline RMSEA & $\geq 0,90$ & 0,930 & $\begin{array}{c}\text { Memenuhi } \\
\text { GFI }\end{array}$ \\
\hline AGFI & $\leq 2,00$ & 5,469 & $\begin{array}{c}\text { Tidak } \\
\text { Memenuhi }\end{array}$ \\
\hline CMIN/DF & $\geq 0,95$ & $-1,003$ & $\begin{array}{c}\text { Tidak } \\
\text { Memenuhi }\end{array}$ \\
\hline TLI & $\geq 0,95$ & 0,000 & $\begin{array}{c}\text { Tidak } \\
\text { Memenuhi }\end{array}$ \\
\hline CFI & & &
\end{tabular}

Dari Tabel di atas menunjukkan bahwa nilai Chi Square $=16,408$ dengan tingkat signifikansi sebesar 7,81, demikian pula dengan nilai kelayakan yang lain yang belum memenuhi kriteria fit sehingga dapat disimpulkan bahwa terdapat perbedaan antara matriks kovarians sample dengan matriks kovarians populasi yang diestimasi tidak diterima yang berarti model adalah belum fit. Namun demikian perlu diketahui bahwa Chi Square sangat sensitive terhadap jumlah sample (Ghozali, 2004). Oleh karena itu dicari ukuran model fit yang lain, yaitu nilai GFI sebesar 0,930. Sehingga secara keseluruhan model dapat diterima untuk memberikan konfirmasi yang cukup dan diterima bahwa keempat indikator diatas dapat mencerminkan variable laten yang dianalisis yakni variable pengetahuan.

\section{c. Analisis Konfirmatori Variabel Konsep Diri Dan Nilai-Nilai $\left(\mathrm{X}_{3}\right)$}

Analisis konfirmatori variabel konsep diri dan nilai-nilai dilakukan untuk mengkonfirmasi apakah indikator yang diamati dapat mencerminkan faktor yang dianalisis yaitu variabel konsep diri dan nilai-nilai. Adapun hasil analisis konfirmatori yang dilakukan terhadap variabel konsep diri dan nilai-nilai diuraikan di bawah ini :

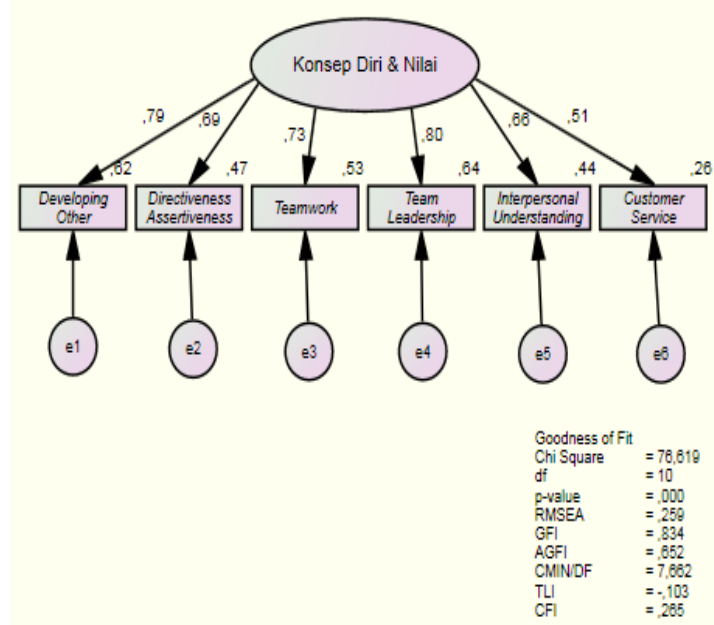

Gambar 4

Hasil Analisis Konfirmatori Variabel Konsep Diri dan Nilai-Nilai

Untuk melakukan analisis konfirmatori variabel konsep diri dan nilainilai, uji dasar yang harus dilakukan yaitu dengan menguji kesesuaian modelGoodness of Fit Test, hasil pengujian kesesuaian model pada konfirmatori 
factor analisis disajikan dalam Tabel di bawah ini :

Tabel 9

Hasil Pengujian Kelayakan Variabel Konsep Diri dan Nilai-Nilai

\begin{tabular}{|l|c|c|c|}
\hline $\begin{array}{c}\text { Goodness of } \\
\text { Fit Indeks }\end{array}$ & $\begin{array}{c}\text { Cut off } \\
\text { Value }\end{array}$ & Hasil & Evaluasi Model \\
\hline Chi-Square & $\leq 18,31$ & 76,619 & Tidak Memenuhi \\
\hline DF & $\geq 0,05$ & 0,000 & Tidak Memenuhi \\
\hline P-Value & $\leq 0,08$ & 0,259 & Tidak Memenuhi \\
\hline RMSEA & $\geq 0,90$ & 0,834 & Tidak Memenuhi \\
\hline GFI & $\geq 0,90$ & 0,652 & Tidak Memenuhi \\
\hline AGFI & $\leq 2,00$ & 7,662 & Tidak Memenuhi \\
\hline CMIN/DF & $\geq 0,95$ & $-0,103$ & Tidak Memenuhi \\
\hline TLI & $\geq 0,95$ & 0,265 & Tidak Memenuhi \\
\hline CFI &
\end{tabular}

Sumber: Data Primer Diolah, 2016

Dari Tabel di atas menunjukkan bahwa nilai Chi Square $=76,619$ dengan tingkat signifikansi sebesar 18,31 demikian pula dengan nilai kelayakan yang lain yang belum memenuhi kriteria fit sehingga dapat disimpulkan bahwa terdapat perbedaan antara matriks kovarians sample dengan matriks kovarians populasi yang diestimasi tidak diterima yang berarti model adalah belum fit. Namun demikian perlu diketahui bahwa Chi Square sangat sensitive terhadap jumlah sample (Ghozali, 2004). Oleh karena itu dicari ukuran model fit yang lain, yaitu GFI mendekati 0,90 yakni 0,834 . Sehingga secara keseluruhan model dapat diterima untuk memberikan konfirmasi yang cukup bahwa keenam indikator diatas dapat mencerminkan masing variable laten yang dianalisis.

\section{d. Analisis Konfirmatori Variabel Karakteristik Pribadi $\left(\mathrm{X}_{4}\right)$}

Analisis konfirmatori variabel karakteristik pribadi dilakukan untuk mengkonfirmasi apakah indikator yang diamati dapat mencerminkan faktor yang dianalisis yaitu variabel karakteristik pribadi. Adapun hasil analisis konfirmatori yang dilakukan terhadap variabel karakteristik pribadi diuraikan di bawah ini :

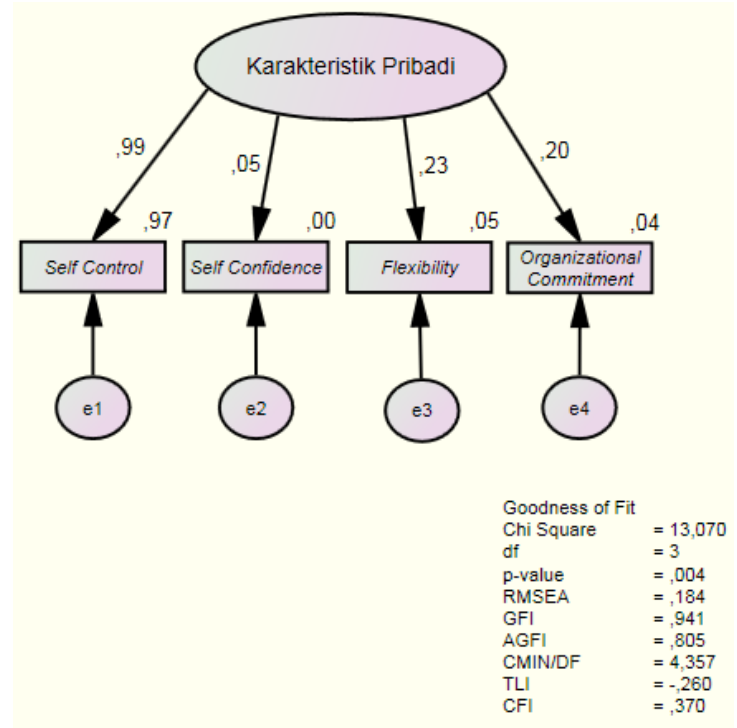

Gambar 5

Hasil Analisis Konfirmatori Variabel Karakteristik Pribadi

Untuk melakukan analisis konfirmatori variabel karakteristik pribadi, uji dasar yang harus dilakukan yaitu dengan menguji kesesuaian model-Goodness of Fit Test, hasil pengujian kesesuaian model pada konfirmatori factor analisis disajikan dalam Tabel di bawah ini :

Tabel 10

Hasil Pengujian Kelayakan Variabel Karakteristik Pribadi

\begin{tabular}{|l|c|c|c|}
\hline $\begin{array}{c}\text { Goodness of Fit } \\
\text { Indeks }\end{array}$ & $\begin{array}{c}\text { Cut off } \\
\text { Value }\end{array}$ & Hasil & $\begin{array}{c}\text { Evaluasi } \\
\text { Model }\end{array}$ \\
\hline Chi-Square & $\leq 7,81$ & 13,070 & $\begin{array}{c}\text { Tidak } \\
\text { Memenuhi }\end{array}$ \\
\hline DF & $\geq 0,05$ & 0,004 & $\begin{array}{c}\text { Tidak } \\
\text { Memenuhi }\end{array}$ \\
\hline P-Value & $\leq 0,08$ & 0,184 & $\begin{array}{c}\text { Tidak } \\
\text { Memenuhi }\end{array}$ \\
\hline RMSEA & $\geq 0,90$ & 0,941 & $\begin{array}{c}\text { Memenuhi } \\
\text { GFI }\end{array}$ \\
\hline AGFI & $\leq 2,00$ & 4,357 & $\begin{array}{c}\text { Tidak } \\
\text { Memenuhi } \\
\text { Memenuhi }\end{array}$ \\
\hline CMIN/DF & $\geq 0,95$ & $-0,260$ & $\begin{array}{c}\text { Tidak } \\
\text { Memenuhi }\end{array}$ \\
\hline TLI & $\geq 0,95$ & 0,370 & $\begin{array}{c}\text { Tidak } \\
\text { Memenuhi }\end{array}$ \\
\hline CFI & & 0,805 & \\
\hline
\end{tabular}

Sumber: Data Primer Diolah, 2016

Dari Tabel di atas menunjukkan bahwa nilai Chi Square $=13,070$ dengan tingkat signifikansi sebesar 7,81 demikian pula dengan nilai kelayakan yang lain yang belum memenuhi kriteria fit 
sehingga dapat disimpulkan bahwa terdapat perbedaan antara matriks kovarians sample dengan matriks kovarians populasi yang diestimasi tidak diterima yang berarti model adalah belum fit. Namun demikian perlu diketahui bahwa Chi Square sangat sensitive terhadap jumlah sample (Ghozali, 2004). Oleh karena itu dicari ukuran model fit yang lain, yaitu nilai GFI lebih besar dari nilai cut off value sebesar 0,941. Sehingga secara keseluruhan model dapat diterima untuk memberikan konfirmasi yang cukup bahwa keempat indikator diatas dapat mencerminkan masing variable laten yang dianalisis.

\section{e. Analisis Konfirmatori Variabel Komitmen Organisasi ( $\left.\mathbf{Y}_{1}\right)$}

Analisis konfirmatori variabel komitmen organisasi dilakukan untuk mengkonfirmasi apakah indikator yang diamati dapat mencerminkan faktor yang dianalisis yaitu variabel komitmen organisasi. Adapun hasil analisis konfirmatori yang dilakukan terhadap variabel komitmen organisasi diuraikan di bawah ini :

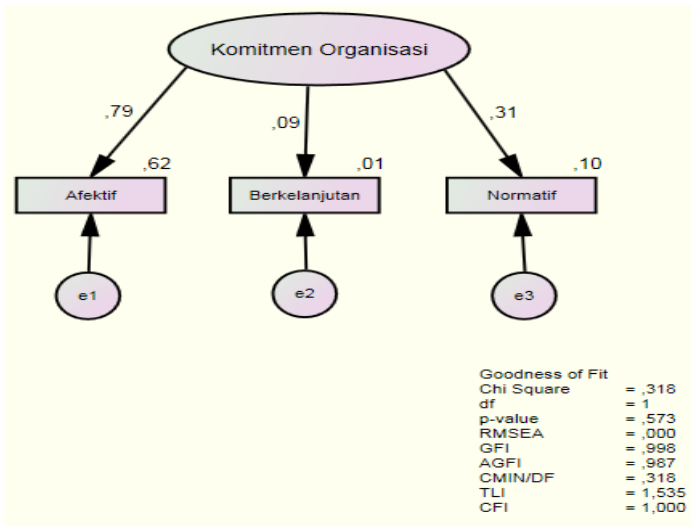

Gambar 6

Hasil Analisis Konfirmatori Variabel Komitmen Organisasi

Untuk melakukan analisis konfirmatori variabel komitmen organisasi, uji dasar yang harus dilakukan yaitu dengan menguji kesesuaian model-Goodness of Fit Test, hasil pengujian kesesuaian model pada konfirmatori factor analisis disajikan dalam Tabel di bawah ini :

Tabel 11

Hasil Pengujian Kelayakan Variabel Komitmen Organisasi

\begin{tabular}{|l|c|c|c|}
\hline $\begin{array}{c}\text { Goodness of Fit } \\
\text { Indeks }\end{array}$ & $\begin{array}{c}\text { Cut off } \\
\text { Value }\end{array}$ & Hasil & $\begin{array}{c}\text { Evaluasi } \\
\text { Model }\end{array}$ \\
\hline Chi-Square & $\leq 3,84$ & 0,318 & Memenuhi \\
\hline DF & $\geq 0,05$ & 0,573 & Memenuhi \\
\hline P-Value & $\leq 0,08$ & 0,000 & Memenuhi \\
\hline RMSEA & $\geq 0,90$ & 0,998 & Memenuhi \\
\hline GFI & $\geq 0,90$ & 0,987 & Memenuhi \\
\hline AGFI & $\leq 2,00$ & 0,318 & Memenuhi \\
\hline CMIN/DF & $\geq 0,95$ & 1,535 & Memenuhi \\
\hline TLI & $\geq 0,95$ & 1,000 & Memenuhi \\
\hline CFI & \multicolumn{2}{|l|}{}
\end{tabular}

Dari Tabel di atas menunjukkan bahwa nilai Chi Square $=0,318$ dengan tingkat signifikansi sebesar 3,84 demikian pula dengan nilai kelayakan yang lain yang memenuhi kriteria fit sehingga dapat disimpulkan bahwa tidak terdapat perbedaan antara matriks kovarians sample dengan matriks kovarians populasi yang diestimasi diterima yang berarti model adalah fit. Sehingga secara keseluruhan model dapat diterima untuk memberikan konfirmasi yang cukup bahwa ketiga indicator yang digunakan dapat mencerminkan variabel laten yang dianalisis yaitu variable komitmen organisasi.

\section{f. Analisis Konfirmatori Variabel Kinerja $\left(\mathrm{Y}_{2}\right)$}

Analisis konfirmatori variabel kinerja dilakukan untuk mengkonfirmasi apakah indikator yang diamati dapat mencerminkan faktor yang dianalisis yaitu variabel kinerja. Adapun hasil analisis konfirmatori yang dilakukan terhadap variabel kinerja diuraikan di bawah ini : 

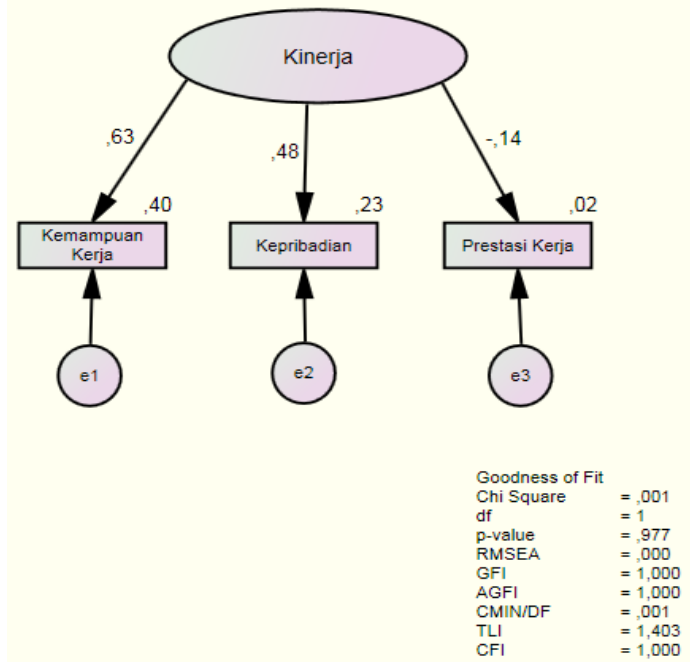

Gambar 7

Hasil Analisis Konfirmatori Variabel Kinerja

Untuk melakukan analisis konfirmatori variabel kinerja, uji dasar yang harus dilakukan yaitu dengan menguji kesesuaian model-Goodness of Fit Test, hasil pengujian kesesuaian model pada konfirmatori factor analisis disajikan dalam Tabel di bawah ini :

Tabel 12

Hasil Pengujian Kelayakan Variabel Kinerja

\begin{tabular}{|l|c|c|c|}
\hline $\begin{array}{c}\text { Goodness of Fit } \\
\text { Indeks }\end{array}$ & $\begin{array}{c}\text { Cut off } \\
\text { Value }\end{array}$ & Hasil & $\begin{array}{c}\text { Evaluasi } \\
\text { Model }\end{array}$ \\
\hline Chi-Square & $\leq 3,84$ & 0,001 & Memenuhi \\
\hline DF & & 1 & \\
\hline P-Value & $\geq 0,05$ & 0,977 & Memenuhi \\
\hline RMSEA & $\leq 0,08$ & 0,000 & Memenuhi \\
\hline GFI & $\geq 0,90$ & 1,000 & Memenuhi \\
\hline AGFI & $\geq 0,90$ & 1,000 & Memenuhi \\
\hline CMIN/DF & $\leq 2,00$ & 0,001 & Memenuhi \\
\hline TLI & $\geq 0,95$ & 1,403 & Memenuhi \\
\hline CFI & $\geq 0,95$ & 1,000 & Memenuhi \\
\hline
\end{tabular}

Sumber: Data Primer Diolah, 2016

Dari Tabel di atas menunjukkan bahwa nilai Chi Square $=0,001$ dengan tingkat signifikansi sebesar 3,84 demikian pula dengan nilai kelayakan yang lain yang memenuhi kriteria fit sehingga dapat disimpulkan bahwa tidak terdapat perbedaan antara matriks kovarians sample dengan matriks kovarians populasi yang diestimasi diterima yang berarti model adalah fit. Sehingga secara keseluruhan model dapat diterima untuk memberikan konfirmasi yang cukup bahwa ketiga indicator yang digunakan dapat mencerminkan variabel laten yang dianalisis yaitu variable kinerja.

\section{Pengujian Hipotesis}

Hasil analisis SEM dari penelitian ini dijabarkan dalam langkah pengujian hipotesis sebagai berikut :

\section{a. Pengujian Hipotesis 1}

$\mathrm{H}_{1}$ : Terdapat pengaruh antara Keterampilan, Pengetahuan, Konsep Diri dan Nilai-nilai, dan Karakteristik Pribadi terhadap Komitmen Organisasi pada Dishubkominfo Kab. Banyumas.

Adapun hasil analisis SEM yang dilakukan diuraikan dalam gambar di bawah ini :

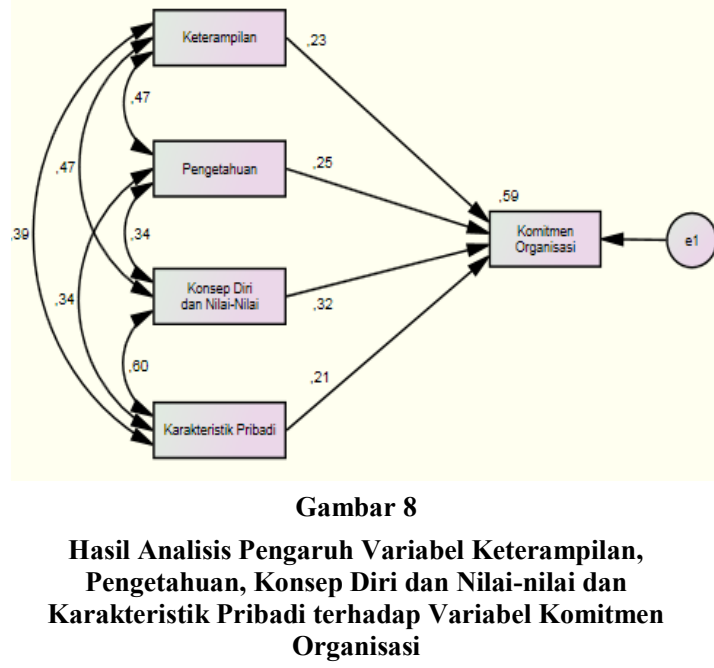

Pada gambar di atas dapat dijelaskan bahwa nilai koefisien regresi terstandar (beta) Keterampilan $\left(\mathrm{X}_{1}\right)$ terhadap Komitmen Organisasi memperoleh nilai sebesar 0,23, Pengetahuan $\left(\mathrm{X}_{2}\right)$ terhadap Komitmen Organisasi memperoleh nilai sebesar 0,25 , Konsep Diri dan Nilai-nilai $\left(\mathrm{X}_{3}\right)$ terhadap Komitmen Organisasi memperoleh nilai sebesar 0,32 dan Karakteristik Pribadi 
$\left(\mathrm{X}_{4}\right)$ terhadap Komitmen Organisasi memperoleh nilai sebesar 0,21. Dari nilai keempat koefisien ini dapat disimpulkan bahwa variable Konsep Diri dan Nilainilai lebih mempengaruhi variable Komitmen Organisasi, dibandingkan dengan variabel Keterampilan, variable Pengetahuan dan variabel Karakteristik Pribadi.

Tabel 13

Variances: (Pipin - Default model)

\begin{tabular}{|l|rrrrl|}
\hline & Estimate & S.E. & C.R. & P & Label \\
\hline X1 & 3,717 &, 528 & 7,036 & $* * *$ & par_11 \\
X2 & 8,301 & 1,180 & 7,036 & $* * *$ & par_12 \\
X3 & 16,921 & 2,405 & 7,036 & $* * *$ & par_13 \\
X4 & 4,398 &, 625 & 7,036 & $* * *$ & par_14 \\
e1 & 3,078 &, 437 & 7,036 & $* * *$ & par_15 \\
\hline
\end{tabular}

Pada tabel 13 diatas dapat dilihat hasil p-value pada kolom $\mathrm{P}$ berupa tiga buah tanda asterisk $(* * *)$, yang berarti nilai p-value sanggat kecil $(<0,001)$, maka dengan demikian bahwa hipotesis yang menyatakan terdapat pengaruh antara Variabel Keterampilan, Pengetahuan, Konsep Diri dan Nilai-nilai dan Karakteristik Pribadi terhadap Variabel Komitmen Organisasi pada pada Dishubkominfo Kab. Banyumas terbukti kebenaraanya.

\section{b. Pengujian Hipotesis 2}

$\mathrm{H}_{2}$ : Terdapat pengaruh antara Keterampilan, Pengetahuan, Konsep Diri dan Nilai-nilai, dan Karakteristik Pribadi terhadap Kinerja pada Dishubkominfo Kab. Banyumas..

Adapun hasil analisis SEM yang dilakukan diuraikan dalam gambar di bawah ini :

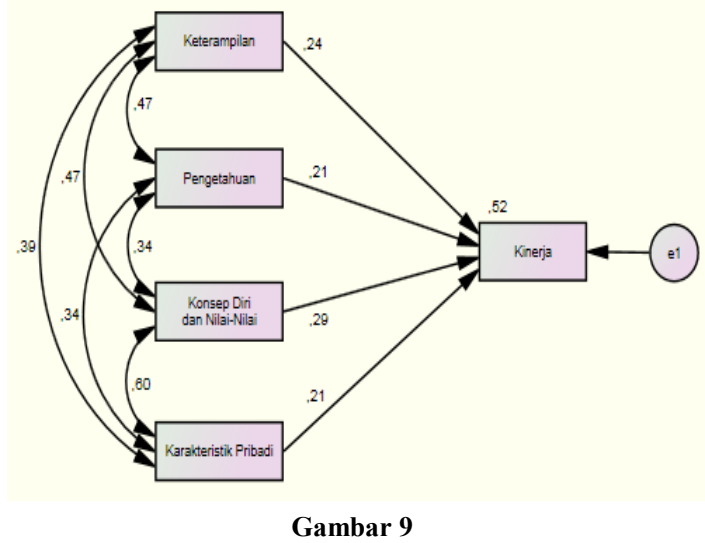

Hasil Analisis Pengaruh Variabel Keterampilan, Pengetahuan, Konsep Diri dan Nilai-nilai dan

Karakteristik Pribadi terhadap Variabel Kinerja

Pada gambar di atas dapat dijelaskan bahwa nilai koefisien regresi terstandar (beta) Keterampilan $\left(\mathrm{X}_{1}\right)$ terhadap Kinerja memperoleh nilai sebesar 0,24 , Pengetahuan $\left(\mathrm{X}_{2}\right)$ terhadap Kinerja memperoleh nilai sebesar 0,21 , Konsep Diri dan Nilai-nilai $\left(\mathrm{X}_{3}\right)$ terhadap Kinerja memperoleh nilai sebesar 0,29 dan Karakteristik Pribadi $\left(\mathrm{X}_{4}\right)$ terhadap Kinerja memperoleh nilai sebesar 0,21. Dari nilai keempat koefisien ini dapat disimpulkan bahwa variable Konsep Diri dan Nilai-nilai lebih mempengaruhi variable Kinerja, dibandingkan dengan variabel Keterampilan, variable Pengetahuan dan variabel Karakteristik Pribadi.

Tabel 14

\begin{tabular}{|c|c|c|c|c|c|}
\hline \multicolumn{6}{|c|}{ Variances: (Pipin - Default model) } \\
\hline & Estimate & S.E. & C.R. & $\mathrm{P}$ & Label \\
\hline $\mathrm{X} 1$ & 3,717 & ,528 & 7,036 & **** & par_11 \\
\hline $\mathrm{X} 2$ & 8,301 & 1,180 & 7,036 & **** & par_12 \\
\hline $\mathrm{X} 3$ & 16,921 & 2,405 & 7,036 & **** & par_13 \\
\hline $\mathrm{X} 4$ & 4,398 & 625 & 7,036 & **** & par_14 \\
\hline e1 & 2,562 & 364 & 7,036 & **** & par_15 \\
\hline
\end{tabular}

Pada tabel 14 diatas dapat dilihat hasil $\mathrm{p}$-value pada kolom $\mathrm{P}$ berupa tiga buah tanda asterisk $(* * *)$, yang berarti nilai p-value sanggat kecil $(<0,001)$, maka dengan demikian bahwa hipotesis yang menyatakan terdapat pengaruh antara Variabel Keterampilan, Penge- 
tahuan, Konsep Diri dan Nilai-nilai dan Karakteristik Pribadi terhadap Variabel Kinerja pada pada Dishubkominfo Kab. Banyumas terbukti kebenaraanya.

\section{c. Pengujian Hipotesis 3}

$\mathrm{H}_{3}$ : Terdapat pengaruh antara Komitmen Organisasi terhadap kinerja pada Dishubkominfo Kab. Banyumas.

Adapun hasil analisis SEM yang dilakukan diuraikan dalam gambar di bawah ini :

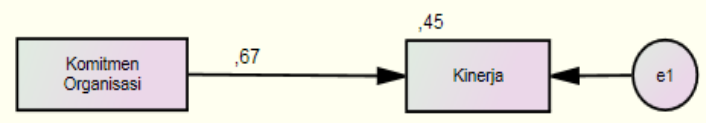

Gambar 10

Hasil Analisis Pengaruh Variabel Komitmen Organisasi terhadap Variabel Kinerja

Pada gambar di atas dapat dijelaskan bahwa nilai koefisien regresi terstandar (beta) Komitmen Organisasi $\left(\mathrm{Y}_{1}\right)$ terhadap Kinerja $\left(\mathrm{Y}_{2}\right)$ memperoleh nilai sebesar 0,67 .

Tabel 15

Variances: (Pipin - Default model)

\begin{tabular}{|l|rrrrr|}
\hline & \multicolumn{1}{|c|}{ Estimate } & S.E. & C.R. & P & Label \\
\hline y1 & 7,542 & 1,072 & 7,036 & $* * *$ & par_2 \\
e1 & 2,905 &, 413 & 7,036 & $* * *$ & par_3 \\
\hline
\end{tabular}

Pada tabel 15 diatas dapat dilihat hasil $\mathrm{p}$-value pada kolom $\mathrm{P}$ berupa tiga buah tanda asterisk $(* * *)$, yang berarti nilai p-value sanggat kecil $(<0,001)$, maka dengan demikian bahwa hipotesis yang menyatakan terdapat pengaruh antara Komitmen Organisasi terhadap Kinerja pada Dishubkominfo Kab. Banyumas terbukti kebenaraanya.

\section{d. Pengujian Hipotesis 4}

$\mathrm{H}_{4}$ : Terdapat pengaruh antara Keterampilan, Pengetahuan, Konsep Diri dan Nilai-nilai dan Karakter- istik Pribadi terhadap kinerja melalui Komitmen Organisasi pada Dishubkominfo Kab. Banyumas.

Adapun hasil analisis SEM yang dilakukan diuraikan dalam gambar di bawah ini :

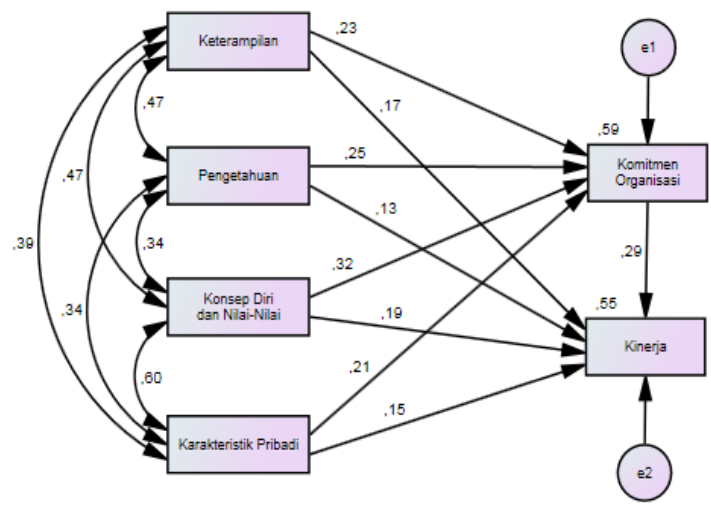

Gambar 11

Hasil Analisis Pengaruh Variabel Keterampilan, Pengetahuan, Konsep Diri dan Nilai-nilai dan Karakteristik Pribadi terhadap Variabel Kinerja melalui Komitmen Organisasi

Pada gambar di atas dapat dijelaskan bahwa nilai koefisien regresi terstandar (beta) Ketarampilan $\left(\mathrm{X}_{1}\right)$, Pengetahuan $\left(\mathrm{X}_{2}\right)$,Konsep Diri dan Nilainilai $\left(\mathrm{X}_{3}\right)$ dan Karakteristik Pribadi $\left(\mathrm{X}_{4}\right)$ terhadap Kinerja melalui Komitmen Organisasi memperoleh nilai sebesar 0,29 .

Tabel 16

Variances: (Pipin - Default model)

\begin{tabular}{|l|rrrrr|}
\hline & Estimate & S.E. & C.R. & P & Label \\
\hline X1 & 3,717 &, 528 & 7,036 & $* * *$ & par_16 \\
X2 & 8,301 & 1,180 & 7,036 & $* * *$ & par_17 \\
X3 & 16,921 & 2,405 & 7,036 & $* * *$ & par_18 \\
X4 & 4,398 &, 625 & 7,036 & $* * *$ & par_19 \\
e1 & 3,078 &, 437 & 7,036 & $* * *$ & par_20 \\
e2 & 2,374 &, 337 & 7,036 & $* * *$ & par_21 \\
\hline
\end{tabular}

Pada table diatas dapat dilihat hasil $\mathrm{p}$-value pada kolom $\mathrm{P}$ berupa tiga buah tanda asterisk $(* * *)$, yang berarti nilai p-value sanggat kecil $(<0,001)$, maka dengan demikian bahwa hipotesis 
yang menyatakan terdapat pengaruh antara Keterampilan, Pengetahuan, Konsep Diri dan Nilai-nilai dan Karakteristik Pribadi terhadap Kinerja melalui Komitmen Organisasi pada Dishubkominfo Kab. Banyumas terbukti kebenaraanya.

\section{SIMPULAN}

Berdasarkan hasil penelitian yang telah dilakukan maka dapat diambil kesimpulan yaitu :

1. Nilai koefisien regresi terstandar (beta) diperoleh Keterampilan $\left(\mathrm{X}_{1}\right)$ terhadap Komitmen Organisasi memperoleh nilai sebesar 0,23, Pengetahuan $\left(\mathrm{X}_{2}\right)$ terhadap Komitmen Organisasi memperoleh nilai sebesar 0,25, Konsep Diri dan Nilainilai $\left(\mathrm{X}_{3}\right)$ terhadap Komitmen Organisasi memperoleh nilai sebesar 0,32 dan Karakteristik Pribadi $\left(\mathrm{X}_{4}\right)$ terhadap Komitmen Organisasi memperoleh nilai sebesar 0,21. Dari nilai keempat koefisien ini dapat disimpulkan bahwa variable Konsep Diri dan Nilai-nilai lebih mempengaruhi variable Komitmen Organisasi, dibandingkan dengan variabel Keterampilan, variable Pengetahuan dan variabel Karakteristik Pribadi. Hal ini dapat dibuktikan dengan nilai signifikansi hasil $\mathrm{p}$-value pada tabel kolom P pada output program Amos Ver 19 yang berupa tiga buah tanda asterisk $(* * *)$, yang berarti nilai $\mathrm{p}$ value sanggat kecil $(<0,001)$, maka dengan demikian bahwa hipotesis yang menyatakan terdapat pengaruh antara Variabel Keterampilan, Pengetahuan, Konsep Diri dan Nilainilai dan Karakteristik Pribadi terhadap Variabel Komitmen Organisasi pada pada Dishubkominfo Kab. Banyumas terbukti kebenaraanya.

2. Nilai koefisien regresi terstandar (beta) Keterampilan $\left(\mathrm{X}_{1}\right)$ terhadap
Kinerja memperoleh nilai sebesar 0,24 , Pengetahuan $\left(\mathrm{X}_{2}\right)$ terhadap Kinerja memperoleh nilai sebesar 0,21, Konsep Diri dan Nilai-nilai $\left(\mathrm{X}_{3}\right)$ terhadap Kinerja memperoleh nilai sebesar 0,29 dan Karakteristik Pribadi $\left(\mathrm{X}_{4}\right)$ terhadap Kinerja memperoleh nilai sebesar 0,21. Dari nilai keempat koefisien ini dapat disimpulkan bahwa variable Konsep Diri dan Nilai-nilai lebih mempengaruhi variable Kinerja, dibandingkan dengan variabel Keterampilan, variable Pengetahuan dan variabel Karakteristik Pribadi. Hal ini dapat dibuktikan dengan nilai signifikansi hasil p-value pada tabel kolom $\mathrm{P}$ pada output program Amos Ver 19 yang berupa tiga buah tanda asterisk $(* * *)$, yang berarti nilai $\mathrm{p}$-value sanggat kecil $(<0,001)$, maka dengan demikian bahwa hipotesis yang menyatakan terdapat pengaruh antara Variabel Keterampilan, Pengetahuan, Konsep Diri dan Nilai-nilai dan Karakteristik Pribadi terhadap Variabel Kinerja pada pada Dishubkominfo Kab. Banyumas terbukti kebenaraanya.

3. Nilai koefisien regresi terstandar (beta) Komitmen Organisasi $\left(\mathrm{Y}_{1}\right)$ terhadap Kinerja $\left(\mathrm{Y}_{2}\right)$ memperoleh nilai sebesar 0,67. Hal ini dapat dibuktikan dengan nilai signifikansi hasil p-value pada tabel kolom $\mathrm{P}$ pada output program Amos Ver 19 yang berupa tiga buah tanda asterisk $(* * *)$, yang berarti nilai p-value sanggat kecil $(<0,001)$, maka dengan demikian bahwa hipotesis yang menyatakan terdapat pengaruh antara Komitmen Organisasi terhadap Kinerja pada Dishubkominfo Kab. Banyumas terbukti kebenaraanya.

4. Nilai koefisien regresi terstandar (beta) Ketarampilan $\left(\mathrm{X}_{1}\right)$, Pengetahuan $\left(\mathrm{X}_{2}\right)$, Konsep Diri dan Nilainilai $\left(\mathrm{X}_{3}\right)$ dan Karakteristik Pribadi 
$\left(\mathrm{X}_{4}\right)$ terhadap Kinerja melalui Komitmen Organisasi memperoleh nilai sebesar 0,29. Hal ini dapat dibuktikan dengan nilai signifikansi hasil p-value pada tabel kolom $\mathrm{P}$ pada output program Amos Ver 19 yang berupa tiga buah tanda asterisk $(* * *)$, yang berarti nilai p-value sanggat kecil $(<0,001)$, maka dengan demikian bahwa hipotesis yang menyatakan terdapat pengaruh antara Keterampilan, Pengetahuan, Konsep Diri dan Nilai-nilai dan Karakteristik Pribadi terhadap Kinerja melalui Komitmen Organisasi pada Dishubkominfo Kab. Banyumas terbukti kebenaraanya.

\section{DAFTAR PUSTAKA}

Amstrong, Michael. 2004. Performance Management. Alih Bahasa: Toni Setiawan. Tugu Publisher. Yogyakarta.

As'ad Moh. 2001. Kepemimpunan Efektif dalam Perusahaan. Yogyakarta : Liberty.

Aznuriyandi, Susi Hendriani dan Machasin. 2014. Pengaruh Kompetensi, Kepemimpinan dan Komunikasi Terhadap Kinerja Karyawan PT. Angkasa Pura II (Persero) Kantor Cabang Bandar Udara Sultan Syarif Kasim II Pekanbaru.

Bacal, Robert. 2005. Performance Management. Alih Bahasa: Surya Dharma \& Yanuar Irawan. PT. Gramedia Pustaka Utama. Jakarta.

Bagia, I Wayan. 2015. Model Konseptual Kinerja Individual Pegawai Pemerintah Daerah Kabupaten Yang Berbasis Kompetensi, Komitmen Organisasi, Dan Motivasi Kerja.

Bernardin, John H., \& Russel, Joyce (1993). Human Resources Management: an Exprerimental Approach. Singapura: Mc Graw-Hill.Inc.

Dharma, Surya. 2005. Manajemen Kinerja; Falsafah Teori dan Penerapannya, Pustaka Pelajar. Yogyakarta.

Donovan,F. \& A.C. Jackson. 1991. Managing Human Service Organizations. N.Y : Prentice Hall, New York.

Dwiyanto, Agus 1995. Kepempimpinan sebagai Ilmu dan Seni. Liberty. Yokyakarta.

Emmyah. 2009. Pengaruh Kompetensi Terhadap Kinerja Pegawai Pada Politeknik Negeri Ujung Pandang.

Faustyna. 2014. Pengaruh Kompetensi Dan Komitmen Pada Tugas Terhadap Kinerja Karyawan Pada Hotel Dharma Deli Medan.

Gibson, Ivancevich Donnelly. 1996. Organisasi Perilaku Struktur Proses. Terjemahan : Nunuk Adiarni. Binarupa Aksara. Jakarta.

Gibson, James L. 1990. Organisasi Perilaku, Struktur, Proses. Erlangga. Jakarta.

Gomes, Fautino Cardosa. 2002. Manajemen Sumber Daya Manusia. Andi Offset. Yokyakarta.

Hasibuan, Malayu S.P. 2006. Manajemen Sumber Daya Manusia (Edisi Revisi). Bumi Aksara. Jakarta.

Kartika, Lucia Nurbani. 2014. Pengaruh Tingkat Kompetensi Terhadap Kinerja Pegawai Administrasi Perkantoran. 
Mangkunegara, A.A. Anwar Prabu. 2005. Evaluasi Kinerja SDM. Refika Aditama. Bandung.

Mangkunegara, Anwar Prabu, 2004. Manajemen Sumber Daya Manusia. Perusahaan cetakan pertama, penerbit PT. Remaja Rsodakarya. Bandung

Meyer, John P., Stanley, David J., Herscovitch, Lynne., and Topolnytsky, Laryssa. 2002. Affective,Continuance, and Normative Commitment to the Organization: A Meta-analysis of Antencendents, Correlates, and Consequences, Journal of Vocational Behaviour, Vol 6. Pp. 20 -52.

Mitrani, Alain. 1995. Manajemen Sumber Daya Manusia Berbasis Kompetensi (terjemahan). PT. Intermasa. Jakarta.

Murgiyono. 2002. Kompetensi Dasar PNS, Konsep Pemikiran Manajemen

Murphy, Kevin R. Jeanette N. Cleaveland. 1995. Understanding Performance Appraisal : Social, Organization and Goal-Based Perspectives. Sage Publications, California.

Robins, Stepen P. 2008. Perilaku Organisasi. Jakarta: Gunung Agung.

Ruky, Achmad, S. 2004; Sistem Manajemen Kinerja. PT. Gramedia Pustaka Utama. Jakarta.

Ruslan Rosady. 2014. Metode Penelitian Public Relation dan Komunikasi. Jakarta : Rajawali Pers.

Sagala, H. Syaiful. 2000. Administrasi Pendidikan Kontemporer. Bandung.

Sambali, Novayanti Prameta. 2015. Pengaruh Kompetensi, Budaya Kerja Dan asilitas Kerja Terhadap Kinerja Pegawai Perwakilan Badan Kependudukan Dan Keluarga Berencana Nasional Provinsi Sulawesi Tengah.

Sangkala. 2007. Knowledge Management. PT. Raja Grafindo Persada. Jakarta.

Sanjaya, I Kadek Edy dan Ayu Desi Indrawati, 2014. Pengaruh Kompetensi, Kompensasi Dan Lingkungan Kerja Terhadap Kinerja Karyawan. Pada PT. Pande Agung Segara Dewata.

Sedarmayanti. 2007. Sumber Daya Manusia dan Produktivitas Kerja, Mandar Maju. Bandung.

Siagian, S.P. 2003. Manajemen Sumber Daya Manusia. Jakarta : Bumi Akasara Indonesia

Sopiah. 2008. Perilaku Organisasional. Yogyakarta : Penerbit Andi

Spencer, Lyle M dan Signe M Spencer. 2003. Competence At Work: Models for Superior Performance. John Wiley and Sons, Inc.

Sriwidodo, Untung dan Agus Budhi Haryanto, Pengaruh Kompetensi, Motivasi, Komunikasi Dan Kesejahteraan Terhadap Kinerja Pegawai Dinas Pendidikan

Sugiyono, 2010. Statistik untuk Penelitian. Bandung: Alfa Beta.

Wulandari, Sandy. 2013. Pengaruh Kompetensi Terhadap Kinerja Karyawan Di Departemen Customer Care Pada PT Toyota Astra Financial Services. 